\title{
Emotional Intelligence and Its Impact on Psychological Contract of it \& Its Employees
}

\author{
Renu Rathi, Usha S
}

\begin{abstract}
In the present environment of economical state, managing the psychological contract of an employee has become very significant and is considered as the company's most profitable asset and valuable resource. The psychological contract includes strong understandings and solid agreements between organization and its workers, beyond the written contract, determining their commitments, expectations, beliefs, promises, and obligations between both parties.

The motivation behind this study is to analyze the relationship between the psychological contract and emotional intelligence. The descriptive research design is used for the present work. A convenient sampling has been used to collect the data. The participants in the survey are 246 employees engaged in IT \& ITes organizations in Bangalore. The tool used for job satisfaction and psychological contract are two self-formulated questionnaires. After the analysis, we conclude that psychological contract is affected by the emotional intelligence. Some of the suggestion based on the study is also presented in this paper.
\end{abstract}

\section{INTRODUCTION}

\section{Emotional Intelligence}

Emotional intelligence refers to the ability to identify and manage one's own emotions, as well as the emotions of others. Emotional intelligence is generally said to include at least three skills: emotional awareness, or the ability to identify and name one's own emotions; the ability to harness those emotions and apply them to tasks like thinking and problem solving; and the ability to manage emotions, which includes both regulating one's own emotions when necessary and helping others to do the same.

Psychological Contract

The psychological contract refers to the unwritten set of expectations of the employment relationship as distinct from the formal, codified employment contract. Taken together, the psychological contract and the employment contract define the employer-employee relationship.

Originally developed by organizational scholar Denise Rousseau, the psychological contract includes informal arrangements, mutual beliefs, common ground and perceptions between the two parties.

Revised Manuscript Received on July 22, 2019.

Dr.Renu Rathi, Assosciate professor, Jain (deemed to be) university, Jayanagar, Bengaluru.

Dr. Usha S, Assistant professor, Jain (deemed to be) university, Jayanagar, Bengaluru
The psychological contract develops and evolves constantly based on communication, or lack thereof, between the employee and the employer. Promises over promotion or salary increases, for example, may form part of the psychological contract.

Managing expectations is a key behavior for employers so that they don't accidentally give employees the wrong perception of action which then doesn't materialize. Employees should also manage expectations so that, for example, difficult situations or adverse personal circumstances that affect productivity aren't seen by management as deviant.

\section{REVIEW OF LITERATURE}

The phrase "psychological contract" is often attributed to Argyris (1960), who speculated on the working relationships observed in a field study. The managers in the organization were promoted from the rank and file employees. When they began their new roles, the managers were already familiar with their subordinate workers. The relationship between manager and subordinates seemed to be sustained by unwritten agreements about how the two parties would work together. Extra break time was acceptable in some circumstances and allowances were shown on both sides. Each party seemed to have an understanding of what was or was not acceptable, despite no written contracts or stated agreements covering the details. Argyris (1960) speculated that the new manager, having been part of the rank and file prior to promotion, knew how to get the best from the employees by accommodating the needs the manager knew so well. The new manager had been socialized into the role and knew what was important, the values in the department and the benefits that were valued.

The promoted managers knew the "give and take" in optimally managing the workers. Argyris referred to this as the psychological contract. The recent literature on the psychological contract has been dominated by the work of Denise Rousseau (including, but not limited to Rousseau, 1989; Rousseau, 1990, 1996, 2001, 2004; Rousseau \& Tijoriwala, 
1998). The psychological contract definition refined by Rousseau extends Argyris' and others' definitions to include mutuality:

"An individual's belief in mutual obligations between that person and another party such as an employer (either firm or another person). This belief is predicated on the perception that a promise has been made (e.g. of employment or career opportunities) and a consideration offered in exchange for it (e.g. accepting a position, foregoing other job offers), binding the parties to some set of reciprocal obligations" (Rousseau \& Tijoriwala, 1998, p. 679).

The psychological contract may be either formally contracted or implied (Herriot, Manning, \& Kidd, 1997). If implied, the perceptions come from the expectations each party holds of the other and communicated either subtly or not so subtly. Each party could have a different perception of the nature of the obligations. Others have argued (e.g. Guest, 2004, Herriot \& Pemberton, 1997) that Rousseau's definition is fundamentally different from that of Argyris (1960) and Schein (1978). The key difference appears to be that Rousseau's approach places more emphasis on the psychological contract being in the mind of the employee. The situation becomes more confused by Rousseau's suggestion that employees vary in their belief that their psychological contract is with their supervisor, management, or "a personification" of the organization (Rousseau, 1998, p. 669).

Rousseau contends that perception, rather than fact of mutuality is the heart of the psychological contract, crediting this insight to Levinson (1965) and Argyris (1960) (Rousseau, 1998). The psychological contract exists at the individual level, representing “a person's beliefs regarding the terms of his or her exchange relationship with another" (Rousseau, 1998, p. 668). The psychological contract is not an implied or third party interpretation, nor a situation where a social unit shares a common set of psychological contracts. Guest (2004), however, maintains there is increasing acknowledgement that the employer's point of view is important in assessing the psychological contract.

As the psychological contract literature moves through this debate, there is an increasing emphasis on finer distinctions on the psychological contract, breach and violation effects. Calls are being made for work defining and discriminating the psychological contract, determining the appropriate levels of analysis and the contextual domain boundaries as different distinctions on the psychological contract (Roehling, 1997). Additional work on the psychological contract would be helpful to expand our understanding of psychological contract fulfillment, the degree of mutuality between employee and employer, as well as the effects of violation. Given that a body of work on the individual's psychological contract already exists, a starting point is to further explore the conceptual clarity of the individual's perceptions of the psychological contract.

\section{RESEARCH METHODOLOGY}

\section{OBJECTIVES OF STUDY}

1. To study the various constructs of Psychological contract.

2. To conceptualize the relationship between the emotional intelligence an d physochologial contract

3. To determine if emotional intelligence predicts the variance explained in the psychological contract.

\section{RESEARCH DESIGN}

The type of research adopted is descriptive research as this research includes survey and fact-finding enquiries to identify the relationship between the Emotional intelligence and the physiological contract of the IT \& ITes employees in Bangalore.

\section{SAMPLE DESIGN}

- Population: The Population for the study includes the entire IT \& ITes employees in Bangalore.

- Sample Size: 246

- Sample Method: A convenient sampling has been used to collect the data.

\section{METHODS OF DATA COLLECTION}

The data is collected through the following sources:

\section{Primary data:}

The tool used for job satisfaction and psychological contract are two self-formulated structured questionnaires.

Secondary data:

The secondary data those which have been already been collected by someone else and which have already been passed through statistical process. In this study, the secondary data are collected through company journals, brochures, Reports etc.

\section{TOOLS USED FOR DATA ANALYSIS}

The collected data is Tabulated and analyzed by setting hypothesis and testing hypothesis.

Using a statistical tools like- Chi-square \& ANOVAs 


\section{RESULT AND DISCUSSION}

Table- I: Data Analysis of Respondent

\begin{tabular}{|c|c|c|c|c|c|}
\hline Particulars & \multicolumn{4}{|c|}{ Number of respondents } & Total \\
\hline Gender & Female & 150 & Male & 96 & 246 \\
\hline \multirow[t]{2}{*}{ Age } & $20-30$ & $31-40$ & $41-50$ & 51 and above & \multirow{2}{*}{246} \\
\hline & 20 & 139 & 32 & 55 & \\
\hline \multirow[t]{2}{*}{ Monthly Income } & Less than 30000 & $30000-50000$ & $50000-100000$ & $\begin{array}{c}\text { More than } \\
100000\end{array}$ & \multirow[t]{2}{*}{246} \\
\hline & 45 & 65 & 25 & 111 & \\
\hline \multirow[t]{2}{*}{ Nature of Job } & Managerial & \multicolumn{2}{|c|}{ Team lead } & Team member & \multirow[t]{2}{*}{246} \\
\hline & 111 & & & 45 & \\
\hline \multirow[t]{2}{*}{ Qualification } & Diploma & \multicolumn{2}{|c|}{ UG } & $\mathrm{PG}$ & \multirow[t]{2}{*}{246} \\
\hline & 34 & & & 72 & \\
\hline \multirow[t]{2}{*}{ Work Nature } & \multicolumn{2}{|c|}{ Permanent } & \multicolumn{2}{|c|}{ Project based } & \multirow[t]{2}{*}{246} \\
\hline & \multicolumn{2}{|c|}{145} & & 101 & \\
\hline
\end{tabular}

The above bifurcation of the respondents profile depicts that out of all respondents 150 of them are females and 96 are males. It is observed that highest fall respondents are in the category of 31-40 years age group which is considered to be a fresh entrants in the industry and might having an experience of few years. Besides that majority respondents did their P.G degree as a part of their educational qualification which is around 72. Moreover nature of employment in the majority of respondent is Permanent which is near to 145.

Table 2: Level of agreement towards Physochologial Contract

\begin{tabular}{|c|c|c|c|c|c|c|c|c|c|c|c|}
\hline & \multicolumn{2}{|c|}{ SA } & \multicolumn{2}{|c|}{$\mathbf{A}$} & \multicolumn{2}{|c|}{ NAND } & \multicolumn{2}{|c|}{ D } & \multicolumn{2}{|c|}{ SD } & \multirow{2}{*}{ Total } \\
\hline & $\mathbf{N}$ & $\%$ & $\mathbf{N}$ & $\%$ & $\mathbf{N}$ & $\%$ & $\mathbf{N}$ & $\%$ & $\mathbf{N}$ & $\%$ & \\
\hline $\begin{array}{l}\text { Feel that maintain a } \\
\text { healthy balance between } \\
\text { work and personal life }\end{array}$ & 41 & 17 & 60 & 24 & 37 & 15 & 77 & 31 & 11 & 4 & 246 \\
\hline $\begin{array}{l}\text { Feel like 're progressing } \\
\text { professionally at the } \\
\text { organization }\end{array}$ & 1 & 0 & 0 & 0 & 11 & 4 & 85 & 35 & 90 & 37 & 246 \\
\hline $\begin{array}{l}\text { Feel, got an ability to } \\
\text { generate new things }\end{array}$ & 146 & 59 & 13 & 5 & 4 & 2 & 2 & 1 & 24 & 10 & 246 \\
\hline $\begin{array}{l}\text { Feel providing upward } \\
\text { feedback to the } \\
\text { supervisor comfortable }\end{array}$ & 18 & 7 & 119 & 48 & 132 & 54 & 69 & 28 & 86 & 35 & 246 \\
\hline $\begin{array}{l}\text { Feel like have enough } \\
\text { freedom to decide how } \\
\text { you do the work }\end{array}$ & 40 & 16 & 54 & 22 & 62 & 25 & 13 & 5 & 35 & 14 & 246 \\
\hline
\end{tabular}

It is seen from the above table that majority respondents agree with the factor of "Feel, got an ability to generate new things, Feel, Feel providing upward feedback to the supervisor comfortable, and disagree with Feel like progressing professionally at the organization.

Table 3: Showing ANOVA (Analysis of Variance) between factors of Emotional Intelligence

Enable us to test for the significance of the differences among more than two samples means.

\begin{tabular}{|c|l|l|l|l|}
\hline Stat.cal Variables & Count & Sum & Average & Variance \\
\hline Self-Awareness. & 229 & 3684 & 16.087 & 7.212 \\
\hline Self-Regulation. & 229 & 3666 & 16.009 & 6.386 \\
\hline Motivation. & 229 & 3166 & 13.825 & 6.759 \\
\hline Empathy. & 229 & 3052 & 13.328 & 3.976 \\
\hline Social Skills. & 229 & 3733 & 16.301 & 7.597 \\
\hline
\end{tabular}


ANOVA

\begin{tabular}{|c|c|c|c|c|c|c|}
\hline Source of variation & $s s$ & $d f$ & $M S$ & $F$ & $\begin{array}{l}P \text {-valu } \\
e\end{array}$ & F crit \\
\hline Between Groups & 2792.104 & 7.000 & $\begin{array}{l}398.87 \\
2\end{array}$ & $\begin{array}{l}72.75 \\
9\end{array}$ & 0.000 & 2.015 \\
\hline Within Groups & 9999.397 & $\begin{array}{l}\text { 1824.00 } \\
\text { 0 }\end{array}$ & 5.482 & & & \\
\hline Total & $\begin{array}{l}12791.50 \\
2\end{array}$ & 1831.000 & & & & \\
\hline
\end{tabular}

Based on the observation, the values from the above Table is: $\mathbf{F}$ ( Observed) Value $>$ F ( Critical ) Value

i.e. observed value lies outside the acceptance region and using it, we will be able to make inferences about whether our samples are drawn from the population having the same mean. $P$ value $<0.05$

It can be concluded that the mean values of the factors of emotional intelligence are not equal and they are not given equal significance in the IT organizations.

\section{Hypothesis Test:}

H0: There is no significant association between Emotional Intelligence and \& Psychological Contract.

$\mathrm{H}_{1:}$ There is a significant association between Emotional Intelligence and \& Psychological Contract.

Table 4: Showing association between Emotional Intelligence and \& Psychological Contract

\begin{tabular}{|l|c|c|c|c|c|}
\hline $\begin{array}{c}\text { Emotional Intelligence / } \\
\text { Psychological Contract }\end{array}$ & High & Medium & Low & Total & Chi square test \\
\hline Self-Awareness. & $\mathbf{1 2}$ & 5 & 5 & 22 & \multirow{2}{*}{ ₹2 $=182.80$} \\
\hline Self-Regulation. & $\mathbf{1 5}$ & 10 & 10 & 35 & \multirow{2}{*}{ P $0.0001 *$} \\
\hline Motivation. & 14 & 21 & $\mathbf{3 0}$ & 65 & \\
\hline Empathy. & 18 & $\mathbf{2 1}$ & 16 & 55 & \\
\hline Social Skills. & 24 & $\mathbf{3 3}$ & 12 & 69 & \\
\hline Total & 83 & 90 & 73 & 246 & \\
\hline
\end{tabular}

\section{INTERPRETATION}

p-value less than 0.05 justifies null hypothesis to be rejected. This means alternate hypothesis that 'there is a significant association between Emotional Intelligence \& Psychological Contract' need to be accepted.

It is also evident from above table that 2 of the responses are concentrated in 'high' of the factors of psychological contract, 2 in medium and one in low factor of psychological contract

Here in this paper several vital aspects reveled related impact of emotional intelligence on factors of psychological contract like Trust worthiness amongst the employee of the organization, support in the problem solving and query resolution, apart from that information and exchange of ideas and feedback to the employee. In the above study observed respondents were the working employees working at selected IT companies in Bangalore. Further the Statistical analysis of the mentioned variables of the Physiological contract revealed that the Psychological contract is significantly impacted by the emotional intelligence of the employees.

\section{REFERENCES}

1. Argyris, C. (1960). Understanding organizational behavior. Homewood, IL: The Dorsey Press.

2. Argyris, C. (1962) Understanding organizational behavior. Homewood, IL: Dorsey.

3. CIPD (2003) Managing the psychological contract, revised January 2007.

http://www.cipd.co.uk/subjects/empreltns/psycntrct/psycontr.htm?IsSrch Res $=1$

4. Coyle-Shapiro, Jacqueline A-M. and Parzefall, M. (2008) Psychological contracts. In: Cooper, Cary L. and Barling, Julian, (eds.) The SAGE handbook of organizational behavior. SAGE Publications, London, UK, pp. 17-34.

5. Denise M. Rousseau(1990)Psychological Contract Inventory Technical Report

6. Frank, M. J. (2006). Hold your horses: A dynamic computational role for the subthalamic nucleus in decision making. Neural Networks, 19, 1120 $-1136$

7. Herriot, P. and Pemberton, C. (1995), A new deal for middle managerse, People Management, 15 June, pp. 32-34 